\title{
The Effect of Irvingia Gabonensis Ethanol Extracts (Ogbono) Seeds on the Growth Rate and Hematological Parameters in Wistar Rats
}

\section{Precious ljeoma Peter* and Mark Victor}

Department of Biochemistry, University of Calabar, Nigeria.

${ }^{*}$ Corresponding author: Precious ljeoma Peter, Department of Biochemistry, Faculty of Basic Medical Sciences, University of Calabar, Nigeria, Tel: +234-7062146990; E-mail: preciouspeter3173@gmail.com

Received date: May 12, 2020; Accepted date: May 25, 2020; Published date: June 5, 2020

Citation: Peter PI, Victor M (2020) The Effect of Irvingia Gabonensis Ethanol Extracts (Ogbono) Seeds on the Growth Rate and Hematological Parameters in Wistar Rats. J Biomedical Sci Vol.9 No.2:3.

\section{Abstract}

Aim: To evaluate the effect of Irvingia gabonensis ethanol extract on the growth-rate and haematological parameters in Wistar rats.

Method: This research was a randomized-controlled study of two groups using ten Male Wistar strain rats within the age of two months, weighing $80 \mathrm{~g}-146 \mathrm{~g}$. Group one as the control and Group two as the test. During the study, distilled water and rat feed was given to the group one, and an oral administration of $250 \mathrm{mg} / \mathrm{kg}$ Irvingia gabonensis was given to group two for 14 days using oral gavage. The growth rate of the Wistar rats was measured as its length using a tape rule within 3 days throughout the study period. Finally, blood samples were obtained for haematological analysis using the BC-5380 Auto Haematology Analyzer.

Result: We discovered that an oral administration of 250 $\mathrm{mg} / \mathrm{kg}$ Irvingia gabonensis significantly increased $(p<0.05)$ the Mean Corpuscular Haemoglobin Concentration $(34+0.27) \mathrm{g} / \mathrm{dl}$ of the test group when compared to the control $(33.23+0.23) \mathrm{g} / \mathrm{dl}$. However, the result didn't indicate a significant change in the growth rate of both groups during the 14 days of study.

Conclusion: The ethanol extract of Irvingia gabonensis seeds doesn't negatively affect blood parameters. Thus, suggesting the use of Irvingia gabonensis extract for the maintenance of normal blood function.

Keywords: Irvingia gabonensis; Haematology analyser; blood parameters; Haemoglobin

\section{Introduction}

Haematology plays a vital role in medicine, it is the study of blood, blood-forming organs, and blood diseases. Blood diseases are associated with genes, infections, side effects of drugs, and lack of certain nutrients in the diet. Also, a common diet-induced blood disorder is anaemia, which is marked by an abnormal reduction in red blood cells. According to WHO, the estimated number of anaemic persons was about 2 billion, and approximately $50 \%$ of all cases were attributed to iron deficiency [1]. Numerous studies have shown that there is an association between early life nutrition and normal growth and development. Not only is nutrition vital in the growth and development of humans and animals, but also in the prevention and treatment of diseases [2,3]. Furthermore, the proper amount of food plays a role in the complete health of an individual and an appropriate growth progression is considered a harbinger of adequate nutrient intake and good health $[4,5]$.

Haematological parameters are blood parameters that serve the purpose of identifying anaemia; inflammatory processes; the state of the vascular wall; suspicion of helminthic infestation; and suspicion of malignant processes in the body [6]. The various haematological parameters include Red Blood Cells, Mean Cell Volume, Haemoglobin, Haematocrit, Mean Corpuscular Haemoglobin Concentration, and Platelet. Blood cells perform a variety of functions including the delivery of oxygen by erythrocytes, the formation of blood clots, the defence against infectious organisms, and immune regulation $[6,7]$.

In 2012, a study was conducted by Omonkhua and Onoagbe [8]. However, the aqueous stem bark extract of Irvingia gabonensis was used to evaluate the various haematological parameters. The study by Omonkhua and Onoagbe [8] revealed a significant increase in red blood cell count, packed cell volume, haemoglobin volume, mean corpuscular haemoglobin and mean corpuscular haemoglobin concentration. They noted that the white blood cell and differential counts were largely unaffected by the plant extract. Also, they stated that Irvingia gabonensis has a protective effect on blood profile.

Five years after the research conducted by Omonkhua and Onoagbe [8], a group of researchers [9] carried out a similar study. According to their findings, the aqueous leaf and stem bark extract of Irvingia gabonensis had no significant difference from the control group when the haematological parameters were assessed. Also, in that same year, a study was conducted by Efosa GE, et al. [10] using the ethanol leaf extract of the plant. Their findings indicated an attenuation in 
the levels of all haematological parameters on cadmium exposed Wistar albino rats. They noted that the leaf ethanol extract of this plant may be useful in mitigating cadmiuminduced haematological disturbances.

The uncertainty of the impact of this plant remains a problem due to contradictory findings from these researchers. Irvingia gabonensis is known as African mango or wild mango. In Nigeria, there are several local names for Irvingia gabonensis such as Apon, Ogbono, and Goron [11]. It is widely distributed in countries such as Nigeria, Cameroon, Central African Republic, Congo, Ghana, and several other African countries. Also, the kernels of this wild mango constitute the most important product and they are used as a food thickening in soups and stews in West African dishes. According to Vossien and Mkamilo [12], the nutritive value of kernel per 100 g edible portion includes; water, protein, fat, carbohydrate, calcium, iron thiamine, riboflavin and niacin. In Nigeria, the kernel is commonly used in the preparation of a popular dish called Ogbono soup. Traditionally, the pulp of this fruit is eaten fresh and the kernel is used as a food additive $[13,14]$. The nutritional component of food has a huge impact on the human body such as growth as well as some disease conditions. Nutritional Growth Retardation (NGR) is more prevalent in populations at risk of poverty [5]. The present study was conducted to compare the effect of the seed extracts with the previous research works carried out using the stem bark extract of Irvingia gabonensis on some haematological parameters.

\section{Materials and Methods}

\section{Irvingia gabonensis extract}

Fresh seeds of the plant were obtained from Watt Market in Calabar, Cross-Rivers State, and then preserved in a basket before commencing the extraction process.

\section{Extraction process}

First, the seed was weighed using a beam balance and then ground into a powdered form. $300 \mathrm{ml}$ of ethanol was used for the extraction. The ground seed was soaked in the ethanol for 48 hours. In addition to this, the liquid was sieved to separate the leftover particles. This process was carried using a filter paper followed by a Whatman filter which was placed in a funnel attached to a conical flask. Finally, the extract was dissolved in dimethyl sulfoxide (DMSO). DMSO is used in smaller quantities due to its toxicity.

\section{Experimental design}

Preparation of animals: The present study was carried out to investigate the effect of ethanol extract of Irvingia gabonensis on the haematological parameters in Wistar rats. A total of Ten albino Wistar rats weighing between $80 \mathrm{~g}-146 \mathrm{~g}$ were obtained from the animal house at the University of Calabar, Calabar. The animals were maintained under standard animal house conditions and given access to rat feed and water ad libitum for two weeks. The water was given through a straw attached to a bottle.

Administration and treatment of animals: The animals were randomly divided into two groups, with five animals placed in each standard animal cage at the animal house. The dose of $250 \mathrm{mg} / \mathrm{kg}$ of Irvingia gabonensis was administered twice daily to the test group using oral gavage and the control group was given only distilled water.

Determination of growth rate: The growth of the rat was determined using a measuring tape. The rats were held firmly but not tightly without inflicting pain on them. And the measurement was taken from the head down to the tail. The length of the rats in each group was noted on a paper. The process was repeated in three days throughout the study period.

\section{Collection of the blood sample}

Twelve hours after the last administration (14 days), the rats were anaesthetized in chloroform saturated chamber. Dissecting sets were used to sacrifice the rats. After dissecting, blood samples were collected through cardiac puncture using sterile needles with syringes. The obtained blood was filled into labelled EDTA bottles for haematological analysis.

\section{Determination of haematological parameters}

The blood samples collected from both groups were sent to the haematology department at the University of Calabar Teaching Hospital for analysis. The haematological indices of the blood samples were estimated by using an automatedhaematological analyser.

\section{Statistical analysis}

The data were expressed as mean+standard error of the mean (SEM). The data analysis was carried out using a t-test, and values were expressed as $p<0.05$.

\section{Results}

From Table 1, the result shows an $(34.23+0.27) \mathrm{g} / \mathrm{dl}$ increase in the MCHC level of the test group when treated with 250 $\mathrm{mg} / \mathrm{kg}$ of Irvingia gabonensis compared to control $(33.23+0.23) \mathrm{g} / \mathrm{dl}$. This result was statistically significant at $\mathrm{p}<0.05$. Furthermore, $250 \mathrm{mg} / \mathrm{kg}$ of Irvingia gabonensis caused an increase in the test group but not statistically significant on the levels of the following parameters such as WBC, RBC, HGB, $\mathrm{MCH}$, LYM and HCT when compared with the control group. Also, a decrease was observed in the MCV and PLT of the test group but not statistically significant. 
Table 1: Effect of IG extract on some haematological parameter.

\begin{tabular}{|c|c|c|c|c|c|c|c|c|c|}
\hline & $\begin{array}{l}\text { WBC } \\
\text { cells } / \mu L)\end{array} \quad\left(\begin{array}{ll} & 10^{3}\end{array}\right.$ & $\begin{array}{l}\operatorname{RBC}\left(\begin{array}{ll}\times \\
\text { cells } / \mu \mathrm{L})\end{array}\right. \\
\end{array}$ & $\begin{array}{l}\text { HGB } \\
(g / d L)\end{array}$ & MCV & $\begin{array}{l}\mathrm{MCH} \\
(\mathrm{g} / \mathrm{dL})\end{array}$ & $\mathrm{MCH}$ & PLT & LYM (\%) & НСТ \\
\hline $\begin{array}{l}\text { Control } \\
(n=5)\end{array}$ & $5.40 \pm 1.51$ & $4.97 \pm 0.42$ & $\begin{array}{ll}10.90 & \pm \\
1.10 & \end{array}$ & $\begin{array}{l}65.87 \quad \pm \\
1.26\end{array}$ & $33.23 \pm 0.23$ & $\begin{array}{l}21.90 \quad \pm \\
0.56\end{array}$ & $\begin{array}{l}702.00 \\
60.17\end{array}$ & $\begin{array}{l}4.97 \quad \pm \\
5.96\end{array}$ & $\begin{array}{l}5.40 \\
1.51\end{array}$ \\
\hline Test $(n=5)$ & $8.27 \pm 0.72$ & $5.96 \pm 0.29$ & $\begin{array}{ll}13.17 & \pm \\
0.71 & \end{array}$ & $\begin{array}{l}64.53 \quad \pm \\
0.49\end{array}$ & $\begin{array}{l}34.23 \\
0.27^{*}\end{array}$ & $\begin{array}{l}22.10 \quad \pm \\
0.26\end{array}$ & $\begin{array}{l}408.67 \\
113.62\end{array}$ & $\begin{array}{l}5.96 \\
0.29\end{array}$ & $\begin{array}{l}8.27 \\
0.72\end{array}$ \\
\hline
\end{tabular}

Values are expressed as mean \pm SEM

*significantly different from the control at $p<0.05$

Table 2: Effect of IG rate on growth rate.

\begin{tabular}{|l|l|l|l|l|}
\hline & Day 3 & Day 6 & Day 9 & Day 12 \\
\hline Control & $28.27 \pm 0.47$ & $28.83 \pm 0.42$ & $29.17 \pm 0.38$ & $30.10 \pm 0.26$ \\
\hline Test & $29.80 \pm 0.40$ & $29.70 \pm 0.40$ & $29.93 \pm 0.53$ & $30.33 \pm 0.44$ \\
\hline \multicolumn{2}{|l}{$\begin{array}{l}\text { Values are expressed as mean } \pm \text { SEM } \\
\text { No significance difference between group at } p<0.05\end{array}$} \\
\hline
\end{tabular}

Table 2 shows the effect ethanolic extract of Irvingia gabonensis (IG) on the growth rate of the rats in 14 days. The results were taken in 3 days, and the results on the 12 days were similar to that of the 14th day. From the result shown, there was no significant difference between the two groups, but a slight increase in the growth rate of the treatment group over the 14 days.

\section{Discussion and Conclusion}

The result of our findings revealed that there was no statistically significant difference in the growth rate between the two groups. Also, in our study, the Mean Corpuscular Haemoglobin Concentration (MCHC) of the test group was significantly higher than the control group, while there was no difference in other haematological parameters. Our present findings are contrary to the study conducted by Omonkhua and Onoagbe [8]. In the study made by Omonkhua and Onoagbe [8], there was a significant increase in all blood parameters except for the white blood cells and differential counts. However, our findings in some haematological parameters correlated with the previous study done by Chukwunono et al. [9] which had no significant difference in all blood parameters. The dissimilarity of our present findings with the study made by Chukwunono et al. [9] was observed in the significant difference of the $\mathrm{MCHC}$ level. The variation in our present findings with previous studies might be because the other researchers used the stem barks of the plant and not the seed.

A high level of MCHC is artifacts. They may result from in vivo or invitro haemolysis, lipemia, the presence of Heinz bodies and spherocytosis due to the loss of membrane, and the consequent spherical shape assumed by the cell $[15,16]$. Also, Low level of MCHC is believed to be ascribed to anaemia whereby the red blood cells are smaller than usual and have a decreased level of haemoglobin. Low MCHC values may occur in animals with regenerative anaemia, and it may also occur in animals with chronic iron deficiency anaemia [16,17]. The $\mathrm{MCHC}$ is low in iron deficiency because there is inadequate iron to support the synthesis of normal amounts of haemoglobin [16].

According to Mary and Charles [18], the normal range value of $\mathrm{MCHC}$ level for 8-16 weeks old male Wistar rats vary from $32.9 \mathrm{~g} / \mathrm{dl}-37.5 \mathrm{~g} / \mathrm{dl}$ and that for females vary from $33.2 \mathrm{~g} /$ $\mathrm{dl}-37.9 \mathrm{~g} / \mathrm{dl}$. This shows that the test group and control group fall within the normal range of the MCHC. That is, $34.23 \mathrm{~g} / \mathrm{dL}$ and $33.23 \mathrm{~g} / \mathrm{dL}$ respectively. But the test group has a more improved $\mathrm{MCHC}$ value than the control. This could be due to the iron content said to be found in the Irvingia gabonensis seed. According to Vossien and Mkamilo [12], the nutritive value of kernel per $100 \mathrm{~g}$ edible portion includes; water, protein, fat, carbohydrate, calcium, iron, thiamine, riboflavin, and niacin. Hence, this study implies that Irvingia gabonensis maintains the normal functioning of blood $[19,20]$.

\section{Ethics Approval and Consent to Participate}

Not applicable.

\section{Consent for Publication}

Not applicable.

\section{Availability of Data and Materials}

All the data we used to validate our current study were accessed from the following published articles:

Omonkhua AA, and Onoagbe LO. Hematological evaluation of normal rabbits treated with aqueous stem bark extracts of Irvingia gabonensis for twenty-four weeks. J Medicine and Biomedical Sciences 2012; 11(2):32-43. Accessed from https:// www.researchgate.net/publication/ 
287281011_Haematological_evaluation_of_normal_rabbits_tr eated_with_aqueous_stem_bark_extracts_of_Irvingia_gabone nsis_for_twenty-four_weeks. The doi was not available.

Ezeasor CK, Chukwuma C, Ekere, SO. et al. Subchronic toxicity studies of aqueous leaf and stem bark extract of Irvingia gabonensis in male albino Wister rats. Comp Clin Pathol 26, 553559 (2017). https://doi.org/10.1007/ s00580-017-2417-3.

\section{Competing Interests}

The authors declare that they have no competing interests.

\section{Funding}

The project was funded by both authors.

\section{Authors' Contributions}

$\mathrm{PI}$ and MV both experimented. PI sent the blood samples to the University of Calabar teaching hospital for Hematological analysis, and MV did the statistical analysis. Both authors wrote and read the manuscript.

\section{Acknowledgment}

We want to first acknowledge Dr. N.M Essien our lecturer/ supervisor at the University of Calabar who guided us throughout the research. Also, the staffs at the animal house for their assistance and provision of animal feeds

\section{Authors' Information}

Both authors are BSc holders in the field of biochemistry at the University of Calabar.

\section{References}

1. Kayode OO, Adeolu OO (2012) Anaemia in developing countries: burden and prospects of prevention and control. Intech open Book, pp: 116-128.

2. Lee A, Cheung CK, Lo K, Keung VM, Mui LW, et al. (2017) Studying Impact of Nutrition on Growth (SING): a prospective cohort for compromising the health outcomes of young children with the dietary quality score. BMJ Open 7: e018380.

3. Sarah DO, Robert R, Dennis B, David MK, Zhaoping L, et al. (2013) Nutrition research to affect food and a healthy life span. J Nutri 143: 1349-1354.

4. Alamgir K, Sami UK, Salahuddin K, Baber NK, Khan M, et al. (2018) Nutritional complications and its effects on human health. J Food Sci Nutri 1: 17-20.

5. Fima L (2010) Nutrition and growth. J Clin Res Pediatr Endocrinol 1: 157-163.

6. Emmanuel CB, Patricia MC, Jeffrey AK, Leigh CJ (1992) Haematology: Introduction and principles of hematologic diagnosis. New York: Lippincott Williams and Wilkins, pp: 2-4.
7. Alvin HS, Lilli MP (2003) Red blood cell biochemistry and physiology: Haematology for the medical student. New York: Lippincott Williams and Wilkins, p: 17.

8. Omonkhua AA, Onoagbe LO (2012) Hematological evaluation of normal rabbits treated with aqueous stem bark extracts of Irvingia gabonensis for twenty-four weeks. J Med Biomed Sci 11: 32-43.

9. Chukwunonso KE, Chigoue C, Samuel OE, Patrick A (2017) Subchronic toxicity studies of aqueous leaf and stem bark extract of Irvingia gabonensis in male albino Wistar rats. J Comp Clin Path 26: 553-559.

10. Efosa GE, Oloso EE, Samson AO, Blessing VE (2017) Attenuation of calcium-induced haematological arrangements in wistar albino rats by irvingia gabonensis O'rorke Bail ethanol leaf extract. J Biomed Pharma Sci 4: 169-174.

11. Lesley A, Nick B (2001) Taxonomy and local names: Irvingia gabonensis and Irvingia wombolu a state of knowledge report undertaken for the central African regional program for the environment. London: Oxford Forest Institute: 1-8.

12. Vossien V, Mkamilo GS (2007) Plant resources of tropical vegetables. Netherland: Backheys Publishers, pp: 97-98.

13. Abaelu AM, Akinrisimi EO (1980) Amino acid composition of irvingia gabonensis (Apon) oil, seed proteins. Nig J Nutrition Science 1: 133-135.

14. Jules J, Robert EP (2008) The encyclopaedia of fruits and nut. London: Cambridge University Press, pp: 419-420.

15. Sarma PR (1990) Clinical methods: The history, physical and laboratory examinations. 3rd Ed. Boston: Butterworths, p: 152.

16. John W (2012) Evaluation of erythrocytes. Veterinary Haematology, pp: 49-211.

17. Buch JG (2010) Textbook of quick review of pharmacology. Anaemia, p: 425.

18. Mary LA, Charles B (2008) Clinical laboratory parameters for Crl: WI. Han-3641

19. Oluwafemi AO, Adebola BO, Olajinka A, Basiru OA, Babatunji EO, et al. (2018) Aqueous extract of Carica papaya Linn, roots potentially attenuate arsenic-induced biochemical and genotoxic effects in Wistar rats. J Trad Mod Med 8: 324-334.

20. Khurana I (2006) Red Blood Cells and anaemia-Textbook of Medical Physiology. Elsevier, pp: 141-144. 